\title{
Experimental Study on Metakaolin and GGBS Based Geopolymer Concrete
}

\author{
B. Sarath Chandra Kumar ${ }^{\# 1}$ and K. Ramesh ${ }^{\# 2}$ \\ ${ }^{\# 1}$ Research Scholar, Department of Civil Engineering, K L University, Guntur, Andhra Pradesh, India. \\ ${ }^{\# 2}$ Professor and Head, Department of Civil Engineering, \\ P. V. P. Siddhartha Institute of Technology, Kanuru, Vijayawada, Andhra Pradesh, India. \\ Email: ${ }^{\# 1}$ sarath.9b@gmail.com
}

\begin{abstract}
Construction industry is dominated by new materials which are ecologically violable and feasible solution for ever growing architectural industry. Effort are in progress all over the world to develop environment friendly construction materials which minimizes the utility of natural resources and helps to decrease green house gas emissions in to the atmosphere. The green house gas releases in the atmosphere is increasing day by day due to ordinary Portland cement production. In this connection, Geopolymer is in need, where the binders used in the production of geopolymer concrete is inorganic polymers. Geopolymer concrete will be introduced as an alternative concrete which did not use any cement in its mixture and used Metakaoline and GGBS as alternative cement. $\mathrm{NaOH}$ and $\mathrm{Na}_{2} \mathrm{SiO}_{3}$ were used as activator solution. The fixed ratio of sodium silicate to sodium hydroxide is 2.5 and the concentration of sodium hydroxide is 8 Molar. The geopolymer concrete specimens are casted and tested in the laboratory for compressive strength, Split Tensile Strength and Flexural Strength for 3 Days, 7 Days and 28 days and cured at ambient temperature. This study helps in gaining knowledge about the morophological composition of geopolymer concrete which might result in path-breaking trends in research and construction industry.
\end{abstract}

Keywords - Geopolymer Concrete, Alkali Activators, Compressive Strength, Split Tensile Strength, Flexural Strength.

\section{INTRODUCTION}

Concrete is one of the most widely used construction material. Portland cement production is a major contributor to carbon dioxide emissions. The global warming is caused by the emission of greenhouse gases, such as carbon dioxide, to the atmosphere by human activities. Among the greenhouse gases, carbon dioxide contributes about $65 \%$ of global warming. Many efforts are being made in order to reduce the use of Portland cement in concrete. These efforts include the utilization of supplementary cementing materials such as fly ash, silica fume, granulated blast furnace slag, rice-husk ash and metakaolin, and finding alternative binders to Portland cement. In terms of reducing the global warming, the geopolymer technology could reduce the carbondioxide emission to the atmosphere caused by Cement about $80 \%$ [1]. In this paper, the effort was made to study the strength parameters of geopolymer concrete with GGBS and Metakaoline [2-3].

There are two main constituents of geo polymers, namely the source materials and the alkaline liquids. The source materials for geopolymers based on alumina-silicate should be rich in silicon ( $\mathrm{Si}$ ) and aluminium (Al). These could be natural minerals such as kaolinite, clays, etc. Alternatively, by-product materials such as fly ash, GGBS, etc could be used as source materials. The choice of the source materials for making geopolymers depends on factors such as availability, cost, type of application, and specific demand of the end users. The alkaline liquids are from soluble alkali metals that are usually sodium or potassium based. The most common alkaline liquid used in geo polymerization is a combination of sodium hydroxide $(\mathrm{NaOH})$ and sodium silicate [4-7].

\subsection{Origin of term 'Geopolymer'}

The term "Geopolymer" was first introduced to the world by Davidovits of France resulting in a new field of research and technology. Geopolymer also known as 'inorganic polymer' has emerged as a 'green' binder with wide potentials for manufacturing sustainable materials for environmental, refractory and construction applications [8].

1.2 Need for the Study

- To find an alternative for the ordinary Portland cement.

- To reduce $\mathrm{CO}_{2}$ emission and produce eco-friendly concrete.

- To provide high strength concrete than ordinary Portland concrete. 


\subsection{Objectives of Present Study}

- To make a concrete without using cement (i.e. Geopolymer concrete).

- To study the different Mechanical properties of geopolymer concrete with varying percentages of GGBS and Metakaolin.

\subsection{Metakaolin}

\section{Materials}

It is obtained from the calcination of kaolinitic clay at temperatures ranging from $500-750^{\circ} \mathrm{C}$. The further calcination of kaolinite at higher temperatures leads to the formation of more ordered crystalline phases, such as spinnel, mullite and cristobalite. It is suggested that firing kaolinite at lower temperatures $\left(<500{ }^{\circ} \mathrm{C}\right)$ does not give sufficient energy to break the crystalline structure of kaolinite. As a result, amorphous metakaolinite is not formed. However, calcination at higher temperatures, i.e. higher than a threshold temperature turns the metastable phase, metakaolinite, into more ordered crystalline phases, which are non-reactive upon alkaliactivation. The high amorphicity of metakaolinite leads to the high reactivity when it is activated in alkali solutions. MK has the smallest particle size in comparison to FA or GGBS. The fine and irregular particle shape of MK often mean that MK generally requires more solution for wetting and reaction to take place appropriately [9].

Table 1. Physical Properties of Metakaolin

\begin{tabular}{|c|c|}
\hline Colour & Pink / Off-white \\
\hline Pozzolan Reactivity mg Ca (OH)2 / gm & 900 \\
\hline Average Particle size & 1.4 micron \\
\hline Brightness (ISO) & $75 \pm 2$ \\
\hline Bulk Density (Gms / Ltr) & 320 to 370 \\
\hline Specific Gravity & 2.5 \\
\hline
\end{tabular}

Table 2. Chemical Properties of Metakaolin

\begin{tabular}{|c|c|}
\hline $\mathrm{Al}_{2} \mathrm{O}_{3}$ & $>39.0 \%$ \\
\hline $\mathrm{Fe}_{2} \mathrm{O}_{3}$ & $<0.8 \%$ \\
\hline
\end{tabular}

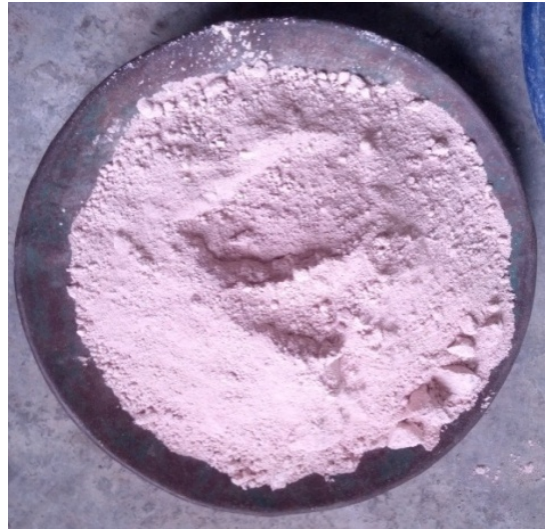

Figure 1. Metakaolin

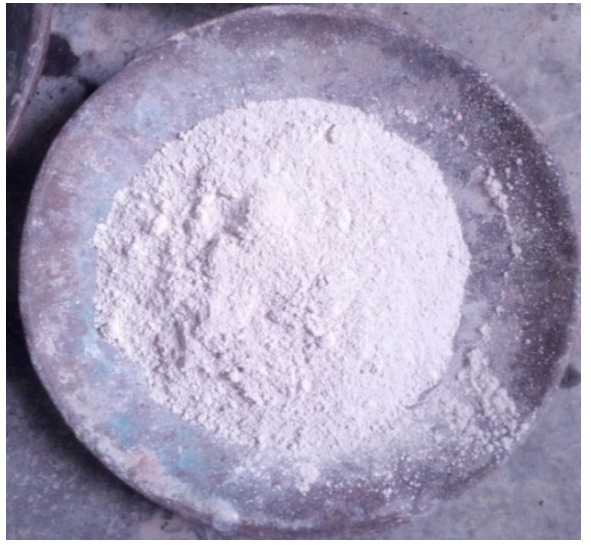

Figure 2. GGBS

\subsection{Ground Granulated Blast Furnace Slag (GGBS)}

GGBS is a by pro duct of the manufacturing of iron in a blast furnace where iron ore, limestone and coke are heated up to $1500^{\circ} \mathrm{C}$. When these materials melt in the blast furnace, two products are produced i.e. molten iron, and molten slag. The molten slag is lighter and floats on the top of the molten iron. The molten slag comprises mostly silicates and alumina from the original iron ore, combined with some oxides from the limestone. The process of granulating the slag involves cooling the molten slag through high pressure water jets. This rapidly quenches the slag and forms granular particles generally not larger than $5 \mathrm{~mm}$ in diameter. The rapid cooling prevents the formation of larger crystals, and the resulting granular material comprises some $95 \%$ noncrystalline calcium alumino silicates. The granulated slag is further processed by drying and then ground to a very fine powder, which is GGBS (ground granulated blast furnace slag) cement it is another excellent cementitious material [10-11]. 
Wainwright and Ait-Aider (1995) examined the influence of the composition of OPC and the addition of up to $70 \%$ GGBS on the bleed characteristics of concrete and conclude that the partial replacement of OPC with $40 \%$ and $70 \%$ of GGBS. GGBS led to increases in the bleeding of the concretes, like fly ash, also GGBS can improve many mechanical and durability properties of concrete and it generates less heat of hydration [12 - 14].

Babu and Kumar (2000) determined the cementitious efficiency of GGBS in concrete at various replacement percentages $(10-80 \%)$ through the efficiency concept by establishing the variation of strength to water-tocementitious materials ratio relations of the GGBS concretes from the normal concretes at the age of 28 days. The 28-day compressive strength of concretes containing GGBS up to $30 \%$ replacement were all slightly above that of normal concretes [15], and at all other percentages, the relationships were below that of normal concretes. It was also observed that the variations due to the different percentages of slag replacement were smaller than the corresponding variations in the case of fly ash [16 - 17]. The result showed that the slag concretes based on overall efficiency factor (k), will need an increase of $8.6 \%$ for $50 \%$ replacement and $19.5 \%$ for $65 \%$ replacement in the total cementitious materials for achieving strength equivalent to that of normal concrete at 28 days [18].

Table 3. Physical Properties of GGBS

\begin{tabular}{|c|c|c|}
\hline Parameter & GGBS & IS : 12089-1987 \\
\hline $\mathrm{CaO}$ & $37.34 \%$ & --- \\
\hline $\mathrm{Al}_{2} \mathrm{O}_{3}$ & $14.42 \%$ & --- \\
\hline $\mathrm{Fe}_{2} \mathrm{O}_{3}$ & $1.11 \%$ & --- \\
\hline $\mathrm{SiO}_{2}$ & $37.73 \%$ & --- \\
\hline $\mathrm{MgO}$ & $8.71 \%$ & Max. 17\% \\
\hline $\mathrm{MnO}$ & $0.02 \%$ & Max. 5.5\% \\
\hline Sulphide Sulphur & $0.39 \%$ & Max. 2\% \\
\hline Loss of Ignition & $1.41 \%$ & --- \\
\hline Insoluble Residue & $1.59 \%$ & Max. 5\% \\
\hline Glass Content (\%) & $92 \%$ & Min. 85\% \\
\hline
\end{tabular}

\subsection{Coarse Aggregate}

Coarse aggregate are a broad category particulate inert materials used in construction. Hard stones are crushed to the required size and are used as coarse aggregate. The material that is retained on as IS sieve of size 4.75 is called coarse aggregate. Aggregate of essentially the same nominal maximum size and grading will produce concrete of satisfactory workability. These aggregates are bound together by the cement and fine aggregate in the presence of water to form concrete [19-21]. Coarse aggregates of sizes $12 \mathrm{~mm}$ and $20 \mathrm{~mm}$ and fine aggregate taken from a local supplier are used in the present study and the properties as shown in Table 4.

Table 4. Physical Properties of Coarse Aggregate

\begin{tabular}{|c|c|c|c|c|}
\hline \multirow{2}{*}{$\begin{array}{l}\text { Sieve Size } \\
\quad(\mathrm{mm})\end{array}$} & \multicolumn{2}{|c|}{$20 \mathrm{~mm}$} & \multicolumn{2}{|c|}{$12 \mathrm{~mm}$} \\
\hline & $\begin{array}{l}\text { Requirement as per } \\
\text { IS: } 383-1970\end{array}$ & Percentage passing & $\begin{array}{l}\text { Requirement as per } \\
\text { IS:383-1970 }\end{array}$ & Percentage passing \\
\hline 80.00 & ---- & ---- & ---- & ---- \\
\hline 63.00 & $\begin{array}{ll}--- \\
\end{array}$ & $\begin{array}{ll}--- \\
--1\end{array}$ & $\begin{array}{ll}--- \\
\end{array}$ & $\begin{array}{ll}--- \\
\end{array}$ \\
\hline 40.00 & $100 \%$ & $100 \%$ & $\begin{array}{ll}--- \\
\end{array}$ & $\begin{array}{ll}--- \\
\end{array}$ \\
\hline 20.00 & $85-100 \%$ & $94.60 \%$ & ---- & ---- \\
\hline 16.00 & ---- & ---- & $100 \%$ & $100 \%$ \\
\hline 12.50 & ---- & ---- & $85-100 \%$ & $93.4 \%$ \\
\hline 10.00 & $0-20 \%$ & $14.30 \%$ & $0-45 \%$ & $39.23 \%$ \\
\hline 4.75 & $0-05 \%$ & $2.85 \%$ & $0-10 \%$ & $6 \%$ \\
\hline 2.36 & $\begin{array}{ll}--- \\
\end{array}$ & ---- & ---- & $\begin{array}{ll}--- \\
\end{array}$ \\
\hline \multicolumn{2}{|c|}{ Specific gravity } & 2.82 & - & 2.79 \\
\hline \multicolumn{2}{|c|}{ Water Absorption \% } & 0.40 & - & 0.48 \\
\hline \multicolumn{2}{|c|}{ Aggregate Impact Value } & $12 \%$ & - & $13 \%$ \\
\hline \multicolumn{2}{|c|}{ Bulk Density $\left(\mathrm{kg} / \mathrm{m}^{3}\right)$} & 1660 & - & 1655 \\
\hline \multicolumn{2}{|r|}{ Flakiness } & $14 \%$ & - & $15 \%$ \\
\hline \multicolumn{2}{|r|}{ Elongation } & $15 \%$ & - & $16 \%$ \\
\hline
\end{tabular}




\subsection{Fine Aggregate}

Fine aggregate should consist of natural sand or crushed stone sand. It should be hard, durable and clean and be free from organic matter etc. fine aggregate should not contain any appreciable amount of clay balls and harmful impurities such as alkalis, salts, coal, decayed vegetation etc[22]. The silt contents should not exceed 4\% [23].

Table 5. Physical Properties of Fine Aggregate

\begin{tabular}{|c|c|c|c|}
\hline I.S. Sieve (mm) & $\begin{array}{l}\text { Percentage Passing } \\
\text { through I.S. Sieve }\end{array}$ & $\begin{array}{c}\text { Percentage Passing I.S. } \\
\text { Sieve as per IS } 383\end{array}$ & \multirow{9}{*}{$\begin{array}{c}\text { Fineness modulus }=2.2 \\
\text { Specific Gravity }=2.50 \\
\text { Bulk Density }=1625 \mathrm{Kg} / \mathrm{m}^{3} \\
\text { Bulking of Sand }=23 \% \\
\text { Silt Content }=0.25 \%\end{array}$} \\
\hline 10 & 100 & 100 & \\
\hline 4.75 & 99.6 & $90-100$ & \\
\hline 2.36 & 99 & $75-100$ & \\
\hline 1.18 & 92.6 & $55-90$ & \\
\hline 600 micron & 48.6 & $35-50$ & \\
\hline 300 micron & 8.2 & $8-30$ & \\
\hline 150 micron & 2 & $0-10$ & \\
\hline Zone & \multicolumn{2}{|c|}{ II } & \\
\hline
\end{tabular}

\subsection{Sodium Hydroxide}

The most common alkaline activator used in geopolymerisation is a combination of sodium hydroxide $(\mathrm{NaOH})$ or potassium hydroxide $(\mathrm{KOH})$ and sodium silicate or potassium silicate. The type and concentration of alkali solution affect the dissolution of fly ash. Leaching of $\mathrm{Al} 3+$ and $\mathrm{Si} 4+$ ions are generally high with sodium hydroxide solution compared to potassium hydroxide solution. Therefore, alkali concentration is a significant factor in controlling the leaching of alumina and silica from fly ash particles, subsequent geo polymerization and mechanical properties of hardened geopolymer ${ }^{16}$. In presence of $\mathrm{NaOH}$ in the activating solution the reaction proceeds more rapidly and the gel is less smooth. The gel composition analysed in the sample activated with the mixture of sodium silicate and $\mathrm{NaOH}$ is enriched in $\mathrm{Na}$ and $\mathrm{Al}$ [24].

\subsection{Sodium Silicate}

Palomo et al (1999) concluded that the type of activator plays an important role in the polymerization process. Reactions occur at a high rate when the alkaline activator contains soluble silicate, either sodium or potassium silicate, compared to the use of only alkaline hydroxides. A study conducted by Xu and Van Deventer showed that the addition of sodium silicate solution to the sodium hydroxide solution as the alkaline activator enhanced the reaction between the source material and the solution ${ }^{21}$. Tempest et al (2009) state that the sodium silicate activator dissolves rapidly and begins to bond fly ash particles. Open porosity can be observed and is rapidly filled with gel as soon as the liquid phase is able to reach the ash particles. The liquid phase is important as a fluid transport medium permitting the activator to reach and react with the fly ash particles [21], [31 - 32].

\subsection{Casting Procedure}

Generally the fine aggregate, coarse aggregate and fly ash are weighed to the required quantities and then they are mixed in dry condition foe 2-3 minutes and then the alkaline solutions prepared (combination of sodium hydroxide and sodium silicate) are to be taken to required quantity is added to the dry mix. This mixing is done for 5-7 minutes in the mixer for proper bonding of all the materials [21, 25]. After the mixing is done the mix is filled in the cube moulds of size $150 \mathrm{~mm} \times 150 \mathrm{~mm}$ X $150 \mathrm{~mm}$ in 3 layers with equal compacting and the cubes are kept on a vibrating table so that no voids are formed [26].

\section{EXPERIMENTAL DETAILS}

\subsection{Experimental Procedure}

\subsubsection{Mix Design of Geopolymer Concrete}

In the design of geopolymer concrete (GPC mix), coarse and fine aggregates together were taken as $75 \%$ of entire mixture by mass. This value is similar to that used in OPC concrete in which it will be in the range of $75 \%$ to $80 \%$ of the entire mixture by mass. Fine aggregate was taken as $30.8 \%$ of the total aggregates ${ }^{1}$. From the past literatures it is clear that the average density of Cementitious materials based geopolymer concrete is similar to that of OPC concrete $\left(2400 \mathrm{~kg} / \mathrm{m}^{3}\right)$ [22]. Knowing the density of concrete, the combined mass of alkaline liquid and cementitious materials can be arrived. By assuming the ratios of alkaline liquid to cementations materials as 0.45 , mass of metakaolin and mass of alkaline liquid was found out. To obtain mass of sodium hydroxide and sodium silicate solutions, the ratio of sodium silicate solution to sodium hydroxide solution was fixed as 2.5. Extra water (other than the water used for the preparation of alkaline solutions) used respectively to achieve workable concrete $[1,20]$. The mix proportion for geopolymer concrete is given in Table 6 and the different combinations of GGBS and Metakaolin investigated are given in Table 7. 
Table 6. Mix Proportions

\begin{tabular}{|c|c|c|c|c|c|}
\hline Materials Used & $\begin{array}{c}\text { Cementitious } \\
\text { Materials }\end{array}$ & $\begin{array}{c}\text { Fine } \\
\text { Aggregate }\end{array}$ & $\begin{array}{c}\text { Coarse } \\
\text { Aggregate }\end{array}$ & $\begin{array}{c}\text { Sodium } \\
\text { Hydroxide }\end{array}$ & $\begin{array}{c}\text { Sodium } \\
\text { Silicate }\end{array}$ \\
\hline $\begin{array}{c}\text { Quantity of } \\
\text { materials in } \mathrm{kg} / \mathrm{m}^{3}\end{array}$ & 414 & 660 & 1136 & 53 & 133 \\
\hline
\end{tabular}

Table 7. Combinations of GGBS and Metakaolin

\begin{tabular}{|c|c|c|c|c|c|c|c|c|c|c|c|}
\hline Mix ID & M1 & M2 & M3 & M4 & M5 & M6 & M7 & M8 & M9 & M10 & M11 \\
\hline Metkaolin (\%) & 100 & 90 & 80 & 70 & 60 & 50 & 40 & 30 & 20 & 10 & 0 \\
\hline GGBS (\%) & 0 & 10 & 20 & 30 & 40 & 50 & 60 & 70 & 80 & 90 & 100 \\
\hline
\end{tabular}

\subsection{Preparation of Geopolymer Concrete}

To prepare 8 molarity concentration of sodium hydroxide solution, 320 grams (molarity x molecular weight) of sodium hydroxide flakes was dissolved in distilled water and makeup to one litre. The sodium hydroxide solution thus prepared is mixed with sodium silicate solution one day before mixing the concrete to get the desired alkaline solution. The solids constituents of the GPC mix i.e. Metakaoline, GGBS and the aggregates were dry mixed in the mixer for about three minutes. After dry mixing, alkaline solution was added to the dry mix and wet mixing was done for 4 minutes $[1,20]$. Finally extra water was added to achieve workable GPCC $\operatorname{mix}[17]$.

In this experimental work a total of 297 numbers of Geopolymer concrete specimens were cast with various mix ratios as shown in Figure1. The specimens are of $150 \mathrm{~mm}$ side. Before casting machine oil was smeared on the inner surfaces of the cast iron mould. Concrete was poured into the moulds and compacted thoroughly using a tamping rod. The top surface was finished using a trowel. The GPC specimens were removed from the mould after 1 or 2 days based on setting of specimens. The specimens were left at room temperature till the day of testing. Compressive strength test was conducted using a $3000 \mathrm{kN}$ Compression testing machine. The test was conducted as per the relevant Indian standard specifications [1], [26-27].

Table 8. Details of Test Specimen

\begin{tabular}{|c|c|c|c|}
\hline S. No. & Name of Test & Size of the Specimen (mm) & No. of Specimen \\
\hline 1 & Compressive Strength Test & $150 \times 150 \times 150$ & 99 \\
\hline 2 & Split Tensile Test & $150 \times 300$ & 99 \\
\hline 3 & Flexural Strength Test & $500 \times 100 \times 100$ & 99 \\
\hline \multicolumn{2}{|c|}{297} \\
\hline
\end{tabular}

\section{RESUlts AND Discussions}

\subsection{Compressive strength}

The compressive strength of Metakaolin based geopolymer concrete at the age of 3 days 7 days and 28 days are presented in the Figure -3

Table 9. Compressive Strength (MPa)

\begin{tabular}{|c|c|c|c|c|c|c|c|c|c|c|c|}
\hline Mix ID & M1 & M2 & M3 & M4 & M5 & M6 & M7 & M8 & M9 & M10 & M11 \\
\hline 3 Days & 6.01 & 9.46 & 12.03 & 14.77 & 19.17 & 19.76 & 24.96 & 30.51 & 31.68 & 33.75 & 40.50 \\
\hline 7 Days & 8.68 & 12.83 & 15.08 & 20.56 & 22.02 & 28.27 & 30.98 & 33.06 & 37.55 & 38.42 & 45.31 \\
\hline 28 Days & 13.17 & 16.36 & 20.32 & 24.13 & 26.01 & 29.67 & 33.84 & 38.50 & 40.22 & 42.68 & 48.04 \\
\hline
\end{tabular}




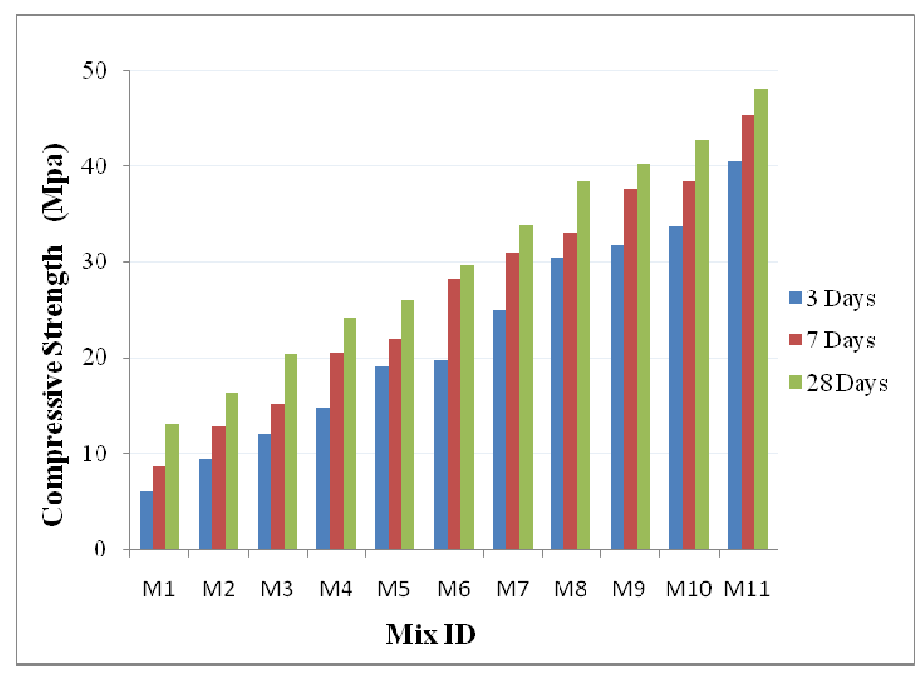

Figure 3. Compressive Strength

Table 10. Percentage Change in Compressive Strength

\begin{tabular}{|c|c|c|c|c|c|c|c|c|c|c|c|}
\hline Mix ID & M1 & M2 & M3 & M4 & M5 & M6 & M7 & M8 & M9 & M10 & M11 \\
\hline $\begin{array}{c}\text { 3 Days to 7days } \\
\text { (\%) }\end{array}$ & 30.81 & 26.26 & 20.24 & 28.15 & 12.95 & 30.07 & 19.42 & 7.70 & 15.64 & 12.14 & 10.63 \\
\hline $\begin{array}{c}\text { 7 Days to 28 } \\
\text { days (\%) }\end{array}$ & 34.10 & 21.60 & 25.75 & 14.79 & 15.35 & 4.72 & 8.46 & 14.15 & 6.64 & 9.99 & 5.68 \\
\hline
\end{tabular}

Compressive strength test on cubes is the most common test conducted on hardened concrete because it is an easy test to perform and most of the desirable properties of concrete are comparatively related to its compressive strength. The compression test was carried out on cubical specimen of size $150 \mathrm{~mm}$ in a compression testing machine of capacity $3000 \mathrm{kN}$. The strength is determined at 3, 7 and 28 days of casting [28]. The variation of compressive strength at the age of $7^{\text {th }}$ and $28^{\text {th }}$ days with optimum percentage of GGBS and Metakaolin were given below in Table 10 From the test results, it was observed that the maximum compressive strength was obtained for mix M11 with 100\% GGBS and least compressive strength is obtained to 100\% Metakaolin and it is also it is observed that the percentage increase in strength from 7 days to 28 days is more in mix M8 i. e. $70 \%$ GGBS and 30\% Metakaoline [25],[31-32].

\subsection{Split Tensile Strength}

Split Tensile Strength of concrete cylinders $150 \mathrm{~mm}$ diameter and $300 \mathrm{~mm}$ long were tested as per the procedure explained in IS 5816 [28].

Table 11. Split Tensile Strength (MPa)

\begin{tabular}{|c|c|c|c|c|c|c|c|c|c|c|c|}
\hline Mix ID & M1 & M2 & M3 & M4 & M5 & M6 & M7 & M8 & M9 & M10 & M11 \\
\hline 3 Days & 1.23 & 1.26 & 1.37 & 1.77 & 2.11 & 2.6 & 3.2 & 4.2 & 4.4 & 5.4 & 6.03 \\
\hline 7 Days & 1.30 & 1.31 & 1.52 & 1.90 & 2.15 & 2.6 & 3.81 & 4.4 & 4.65 & 5.61 & 6.53 \\
\hline 28 Days & 1.37 & 1.41 & 1.55 & 1.96 & 2.21 & 2.94 & 4.14 & 4.53 & 4.9 & 5.87 & 6.8 \\
\hline
\end{tabular}




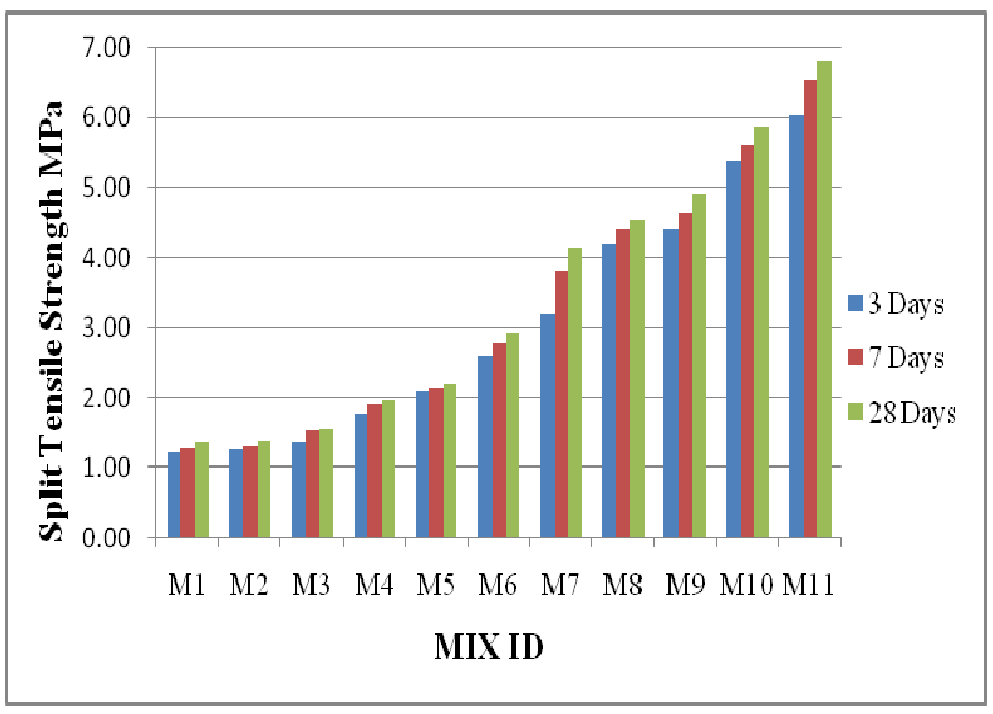

Figure 4. Split Tensile Strength

The values of split tensile strength of cylindrical specimens subjected to ambient curing conditions. The variation of split tensile strength at the age of $28^{\text {th }}$ days with optimum percentage of GGBS and metakaolin were given below. It was observed that the maximum split tensile strength was obtained for mix M11. Also, the split tensile strength decreases with increase in Metakaoline [28].

\subsection{Flexural Strength}

Table 12. Flexural Strength (MPa)

\begin{tabular}{|c|c|c|c|c|c|c|c|c|c|c|c|}
\hline Mix ID & M1 & M2 & M3 & M4 & M5 & M6 & M7 & M8 & M9 & M10 & M11 \\
\hline 3 Days & 0.31 & 0.41 & 0.62 & 0.73 & 0.69 & 0.78 & 1.12 & 1.01 & 1.33 & 1.56 & 2.15 \\
\hline 7 Days & 0.33 & 0.59 & 0.63 & 0.93 & 0.75 & 0.94 & 1.28 & 1.48 & 1.66 & 2.07 & 2.65 \\
\hline 28 Days & 0.44 & 0.65 & 0.68 & 1.01 & 0.98 & 1.04 & 1.33 & 1.55 & 1.71 & 2.31 & 2.97 \\
\hline
\end{tabular}

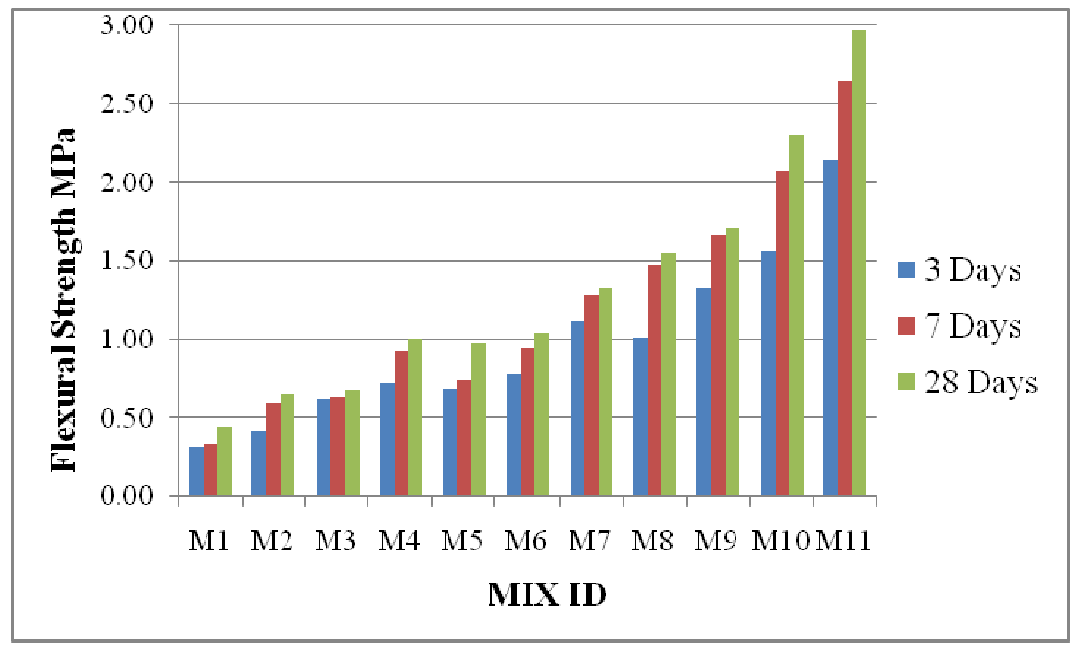

Figure 5. Flexural Strength

The results of flexural strength of concrete at the age of 3, 7 and 28 days are presented in Table 12. The variations in flexural strength at the age of 28 days with different percentage of GGBS and metakaolin were plotted .From the test results, it was observed that when the percentage of GGBS increases, the flexural strength of concrete also increases. On the contrary, the strength decreases when the percentage of metakaolin increases $[28-30]$. 


\section{CONCLUSION}

The conclusions based on the limited observations from the present investigation on properties of fresh and hardened metakaolin and GGBS based concrete are:

1. Workability of geopolymer concrete decreased as the metakaolin content increases with GGBS. But increase in GGBS does not affect the workability.

2. Mechanical properties such as compressive strength, split tensile strength and flexural strength shows increasing trend with the decrease of metakaolin.

3. Mix with $30 \%$ of metakaolin and $70 \%$ of GGBs and seems to have good compressive, split and flexural strengths, this may be due to increase in alkaline reaction between GGBS particles and calcium in Metakaoline.

4. Nearly $90 \%$ of total strength of GPC is achieved within the age of 7days.

5. Then increase in strength of GPC between 7days and 28days appeared to be high when compared with 3 days and 7 days.It shows that even after 7 days geopolymer reaction is taking place but at a higher rate.

\section{VI.ACKNOWLEDGEMENTS}

The authors wish to gratefully acknowledge the support of KaoMin Industries regarding Metakaolin supply and JSW Cements for the supply of GGBS and also the help of the Head of the department and Structural engineering laboratory staff of K L University, Vaddeswaram, Guntur, Andhra Pradesh, India is gratefully acknowledged.

\section{VII.REFERENCES}

[1] K. Vijai, R. Kumutha And B. G. Vishnuram, Experimental Investigations on Mechanical Properties of Geopolymer Concrete Composites, Asian Journal of Civil Engineering (Building and Housing), 2012, 13 (1), 89-96.

[2] M. Nazeer, R. Arun Kumar, Strength Studies on Metakaolin Blended High Volume Fly Ash Concrete, International Journal of Engineering and Advanced Technology (IJEAT), 2014 August, 3 (6), 176 - 179.

[3] P. Sachithanandam, T. P. Meikandaan, Properties and Strength of Glass Fibre Reinforced Geopolymer Concrete, International Journal of Innovative Research in Science, Engineering and Technology, 2015 June, 4 (3), 4409-4416.

[4] Shalika Sharma, Dr. Hemant Sood, Abrasion Resistance of Geopolymer Concrete at Varying Temperature, IOSR Journal of Mechanical and Civil Engineering (IOSR-JMCE), 2016 Jan - Feb, 13 (1). 22 - 25.

[5] K. Ashalatha et al., Mechanical Properties of Geopolymer Concrete by Using Mill Rejected Coal Aggregate as Partial Replacement of Coarse Aggregate, International Research Journal of Engineering and Technology (IRJET), 2016 May, 3 (5), 2796 - 2803.

[6] N. A. Lloyd and B. V. Rangan, Geopolymer Concrete with Fly Ash, Second International Conference on Sustainable Construction Materials and Technologies, 2010 June.

[7] Sanjay N. Pati et al., Metakaolin - Pozzolanic Material for Cement in High Strength Concrete, IOSR Journal of Mechanical and Civil Engineering, 2 (0), 46 - 49.

[8] P. Vignesh, K. Vivek, An Experimental Investigation on Strength Parameters of Flyash Based Geopolymer Concrete with GGBS, International Research Journal of Engineering and Technology (IRJET), 2015 May, 2 (2), 135 - 142.

[9] Harsha Vardhan K., Effects of Metakaolin on Ggbs Based Geopolymer Concretes, Synopsis, 2013 October, S R M University, 1-12.

[10] Alwis Deva Kirupa J. P., Sakthieswaran N., Possible Materials for Producing Geopolymer Concrete and its Performance with and without Fibre Addition- A State of the Art Review, International Journal of Civil and Structural Engineering, 2015, 5 (3). 296 - 307.

[11] Vaishali Sahu, Niragi Dave, Approaches Towards Industrial Byproduct Utilization: A Review Towards Environmentally Safe Future, International Journal of Innovative Research In Science, Engineering and Technology, 2013 July, 2 (7), 2847 - 2855.

[12] Wainwright P. J., Ait-Aider H, The Influence of Cement Source and Slag Additions on The Bleeding of Concrete, Cement and Concrete. Research, 1995, 25 (7): 1445 - 1456.

[13] K. Srinivasan, A. Siva Kumar, Strength Properties of Geopolymer Mortar Containing Binary and Ternary Blends of Bentonite, ARPN Journal of Engineering and Applied Sciences, 2012 November, 7 (11), 1436 - 1445.

[14] Rafat Siddique and Mohammad Iqbal Khan, Supplementary Cementing Materials, Spinger Heidelberg Dordrecht London New York, 2011.

[15] Http://www.Ce.Memphis.Edu/1112/Notes/Project_2/PCA_Manual/Chap09.Pdf/ Dated: 20-10-2016.

[16] Babu K. G., Kumar V. S. R., Efficiency of GGBS In Concrete, Cement And Concrete Research, 2000, 30, 1031-1036.

[17] B Sarath Chandra Kumar et al., Sustainable Development Using Supplementary Cementitious Materials and Recycled Aggregate, International Journal of Modern Engineering Research (IJMER), 2012 January, 2 (1), 165-171.

[18] Http://www.Gharexpert.Com/Tips/Articles/Construction/1475/Fine-Aggregate-1475-Specification-Fine-Aggregate-Coarse-Sand_0/ Date Accessed: 3-11-2016.

[19] S. Jaydeep, B. J. Chakravarthy, Study on Fly Ash Based Geopolymer Concrete Using Admixtures, International Journal of Engineering Trends and Technology (IJETT), 2013 October, 4 (10), 4613-4617.

[20] Suresh G. Patil and Manojkumar, Factors Influencing Compressive Strength of Geopolymer Concrete, International Journal of Research in Engineering and Technology, 2013 November, 372-385.

[21] M. M. A. Abdullah et al., Mechanism and Chemical Reaction of Fly Ash Geopolymer Cement- A Review, International Journal of Pure and Applied Sciences and Technology, 2011, 6 (1), 35-44.

[22] Gabriel Varga. The Structure of Kaolinite and Metakaolin. Epitoanyag, 2007, 59, 6-9.

[23] M. M. A. Abdullah et al., Mechanism And Chemical Reaction of Fly Ash Geopolymer Cement- A Review, International Journal of Pure and Applied Sciences and Technology, 2011, $6(1), 35$ - 44.

[24] B. Vijaya Rangan et al., Studies on Fly-Ash Based Geopolymer Concrete, Geopolymer : Green Chemistry and Sustainable Development Solutions, $133-137$.

[25] Rohit Zende, Mamatha. A, Study on Fly Ash and GGBS Based Geopolymer Concrete under Ambient Curing, Journal of Emerging Technologies and Innovative Research (JETIR), 2015 July, 2 (7), 3082 - 3087.

[26] C. Y. Heah et al., Effect of Curing Profile on Kaolin-Based Geopolymers, International Conference on Physics Science and Technology (ICPST 2011), Physics Procedia, 2011. 22, $305-311$. 
[27] H. Gokulram, R. Anuradha, Strength Studies on Polypropylene Fibre Reinforced Geopolymer Concrete Using M - Sand, International Journal of Emerging Trends in Engineering and Development, 2013 March, 3 (2), 242 - 250.

[28] Kavitha S. and A. Sandhiya devi, Experimental Evaluation of the Influence of Nanosilica on the Properties of Concrete, International Journal of Innovative Science, Engineering \& Technology, 2016 June, 3 (6), 644-648.

[29] Akib S. Dadu, Yamini J. Patel, Vipul H. Vyas, Study on Mechanical Properties of Geopolymer Concrete Using Different Source Material, International Journal of Innovative Research in Science, Engineering and Technology, 2016 May, 5 (5), 8607 - 8616.

[30] B. Sarath Chandra Kumar, K. Ramesh, Experimental Study on Strength Properties of Metakaolin and GGBS Based Geopolymer Concrete, ARPN Journal of Engineering and Applied Sciences, 2016 November, 11 (21), $12414-12422$.

[31] Http://Docplayer.Net/23047047-Chapter-3-Fly-Ash-Based-Geopolymer-Concrete.Html/ Date Accessed: 28-10-2016.

[32] S. P. S. Ramya , A. M. N. Kashyap, An Experimental Study on Durability of Concrete Using Fly Ash \& GGBS for M30 Grade Concrete, International Journal of Engineering Research and Development, 2014 November, 10 (11), 1 -5. 